\title{
EU Quota Sugar Market Concentration - the Main Drivers of EU Sugar Market
}

\author{
H. Řezbová1, M. Maitah ${ }^{1}$ and O. I. Sergienko² \\ ${ }^{1}$ Department of Economics, Faculty of Economics and Management, Czech University of Life Sciences \\ in Prague, Czech Republic \\ 2 Industrial Ecology Department, ITMO University, St. Petersburg, Russia
}

\begin{abstract}
Anotace
Evropský trh s cukrem výrazně mění svůj charakter. V průběhu posledních dvou desetiletí se změnila jeho koncentrace a jednotlivé země a společnosti se začaly připravovat na ukončení systému výrobních kvót na cukr. Úroveň soutěže v rámci trhu s cukrem v EU se zrychluje. Mnoho společností již opustilo trh EU nebo výrazně snížilo své výrobní kapacity. Hlavním cílem tohoto př́spěvku je analyzovat trh s cukrem $\mathrm{v}$ rámci $\mathrm{EU}$, zejména trh cukru v rámci výrobních kvót a specifikovat současné výrobní struktury $\mathrm{v}$ EU. V článku je provedena identifikace klíčových hráčů/subjektů, působících v rámci systému kvótovaného cukru. Záměrem je zjistit úroveň koncentrace trhu s cukrem v EU prostřednictvím Herfindahl-Hirschmanova indexu (HHI). Výsledky, vycházející z analýz poskytují přehled o velmi specifickém charakteru evropského systému výroby cukru v rámci kvót. Ačkoliv se na trhu nachází relativně vysoký počet společností, výrobní kapacity kvótovaného cukru jsou velmi koncentrované. Většina cukrovarů se nachází v Německu, Francii, Polsku a většina cukerních výrobních kvót je ovládána společnostmi se sídlem v Německu, Francii, Nizozemsku a ve Spojeném království. V současné době je systém kvótoveného cukru v Evropské unii provozován/ ř́zen pouze několika velmi silnými subjekty: Südzucker, Nordzucker, Tereos, ABF, Pfeifer \& Langen, Royal Cosun a Cristal Union. Článek byl zpracován v rámci IGA (Interní grantové agentury), PEF, ČZU v Praze, číslo 20151031, „Vybrané aspekty ekonomických sankcí a jejich dopad na vzájemný obchod mezi EU a Ruskem“.
\end{abstract}

\section{Klíčová slova}

Výroba cukru, systém cukerních kvót, rozdělení cukerních kvót, trh s cukrem, trh EU.

\begin{abstract}
The European sugar market is changing its character. During the last two decades its concentration changed and individual countries and companies have been preparing themselves for the end of sugar production quotas system. The level of competition within the EU sugar market is accelerating. Many companies already left the EU market or significantly reduced their production capacities. The main task of this material is to analyse the EU sugar market and especially sugar quotas character and to specify the current EU sugar production structures existing under the sugar quotas system. The paper is also identifying individual drivers/actors operating under the sugar quota system. The idea is to identify the level of EU sugar market concentration through the Herfindahl-Hirschman Index (HHI). The results coming from the analyses provides the overview of very specific character of the European sugar production quota system. However the market is operated by many companies and alliances, its production capacity are extremely concentrated. The majority of sugar plants are located in Germany, France, Poland and the majority of sugar quotas are controlled by companies headquartered in Germany, France, the Netherlands and the United Kingdom. In nowadays - the sugar quota system in the European Union is operated/controlled by only a few very powerful operators: Südzucker, Nordzucker, Tereos, ABF, Pfeifer \& Langen, Royal Cosun and Cristal Union. This paper was supported by the Grant Agency at the Faculty of Economics and Management, Czech University of Life Sciences Prague: The selected aspects of economy sanctions and their impact on mutual trade between EU and Russia [nr. 20151031].
\end{abstract}

\section{Keywords:}

Sugar production, sugar quota system, quota distribution, sugar market, EU market. 
Řezbová, H. Maitah, M., Sergienko, O. I. (2015) "EU Quota Sugar Market Concentration - the Main Drivers of EU Sugar Market", AGRIS on-line Papers in Economics and Informatics, Vol. 7, No. 4, pp. 131- 142, ISSN 1804-1930.

\section{Introduction}

The European beet sugar beet quota system has been developing very dynamically in recent years. Reform measures that have been implemented over the last two decades have significantly influenced its present form and structure (Nolte, Grethe, 2012). Abolishing the common market organization, which is expected to be completed in 2017, seems to be the last planned step in reforming the European sugar system. This reform does not mean that the sugar market will be fully liberalized in the European Union. It will remain partly isolated from the rest of the world due to relatively high tariffs (Nolte et al., 2011; Smutka et al., 2012). Quota abolition will lead to an even greater restructuring of the sugar market within the EU-states (Nolte et al., 2012). A long-term process of forming the sugar quota holder system has led to its gradual profiling across the entire European Union. The number of sugar beet growers and sugar producers has been dynamically declining (Nolte, Grethe, 2011). The reforms have contributed to a significant reduction in production capacities in European countries in recent years. Many traditional sugar production regions have completely abandoned the quota system and the production quota was either completely eliminated or significantly redistributed among other states, respectively among companies controlling European sugar production (Smrčka et al., 2012). In addition, sugar production is becoming more concentrated and some countries, respective multinational companies, which operate in the European market have been able to strengthen their position with key producers (Neundoerfer, 2011; Nolte, Grethe, 2011). The European sugar market is very specific, both in the global economy as well as within the European Single Market. While the production of cane sugar is dominating in the world market, European sugar production is based on sugar beets. It is, to some extent, still surviving „Napoleonic paradoxbecause the cultivation of sugar beet had spread at the time of the Napoleonic wars in Europe when Britain blocked continental ports and thus imports of cane sugar. Until 2017, the European sugar market will be protected not only from cane sugar imports, but also to some extent from its own production within the EU. While there are more than one hundred pure beet sugar factories, other sugar producers (i.e. combined sugar factories and cane refineries capable to process imported raw cane sugar) represent over twenty. The market is largely divided among a limited number of players who have been given permission to do business and to who are generating substantial profits. The Single Market is protected by high tariffs levied on cane sugar imports both raw and refined from the main producers as Brazil or Thailand. Developing countries that have signed preferential agreements with the EU can export sugar to the EU duty-free (Gotor, 2009). The EU market is mostly focused on beet sugar for which the Common Market Organisation and related system of production quotas are applied (Gohin, Bureau, 2005). The European sugar quota system is (only in 2006 was a reform) undergoing many changes and reforms. Many players have left the quota holder system, many others have reduced their production capacities. But on the other hand, a group of a specific players have begun dominating the quota holder system (Spettmann, 2008). The formerly competitive quota holder system has become highly concentrated and competition is very limited. A successful producer groupings in the form of cartels has led to increasing quota holder system concentration which creates unfair competition, forms a common price policy and sets the course of the entire sector (Severová, Bendl, 2013). For example, a recent penalty (2014) was imposed by the German Federal Antimonopoly Authority (Bundeskartellamt) to companies Pfeifer \& Langen $\mathrm{GmbH} \&$ Co. KG (Pfeifer \& Langen), Südzucker AG Mannheim/Ochsenfurt (Südzucker) and Nordzucker AG Braunschweig (Nordzucker), (Finally the cartel was not proved). Market (quota holder system) concentration can be measured by various methods. It can be assumed that the more concentrated the market (system) is, the greater likelihood that firms are capable to abuse its dominant position. The Herfindahl - Hirschman Index is one of the indicators for measuring market (quota holder system) concentration (Hirschman, 1964). In addition, market (quota holder system) concentration can be measured by the "Four-firm concentration ratio" expressed also as "CR4", eventually by "Five-firm concentration ratio" (DG Comp, 2007). The market (quota holder system) concentration can be perceived from two perspectives. On one hand, the concentration of the sugar market restricts competition. On the other hand, market concentration 
within the EU enables it to face other dynamically growing markets outside of the EU (Smutka et al., 2012; Strnadová, 2009). Companies operating in the current sugar quota holder system also have to face other trends such as dynamic research and the development of GM-sugar beet and cane varieties. This increase pressure to cut costs in cultivation (Špička, Janotová, 2013) which becomes an important factor in enhancing labour productivity (Machek, Špička, 2013). Question number one is sustainability of sugar beet growing and beet sugar industry. This sustainability has a fundamental economic aspect regarding competitiveness with cane sugar, and an environmental aspect including mainly the current issue of emissions and foreign chemical substances (Chochola, Pulkrábek, 2012).

Production and trade in sugar are very closely linked with the policies of sustainable development (Smutka, Rumánková, Pulkrábek, Benešová, 2013). The special position of Brazil in relation to global market highlights its influence on the development of world sugar prices (Smutka, 2015).

The main aim of this paper is to analyse the EU sugar market and especially sugar quotas character and to specify the current EU sugar production structures existing under the sugar quotas system.

\section{Materials and methods}

The main objective of this material is to analyse the EU sugar market and especially sugar quotas character and to specify the current EU sugar production structures existing under the sugar quotas system. The paper is also identifying individual drivers/actors operating under the sugar quota system. The idea is to identify the level of EU sugar market concentration through the HerfindahlHirschman Index (HHI). The current sugar market operating under the quota system is specified through the set of the following tasks:

i) Identification of the various types of sugar factories, their geographical locations in the EU-Member States.

ii) Specification of the main actors/drivers operating under the sugar quota production system.

iii) Specification of the sugar production quota concentration at the level of EU-Members.

iv) Specification of the sugar production quota concentration at the level of the EU as a whole.

v) Specification of the sugar production quota concentration at the level of individual sugar companies/alliances operating within the EU market (both without the respect of their headquarter location and also with respect to their main headquarters location).

The analysed data provides an overview of the situation in the EU-quota holder system during the period 2013/2014. Data coming into the analyses are collected from the following sources databases: ISO organizations (The International Sugar Organization), F.O.Licht: International-sugar-and-sweetener-report (Licht, 2014), CEFS: CEFS SUGAR STATISTICS (CEFS, 2014), European Commission DG Agri: Sugar and isoglucose balance sheets (European Commission, 2014) and Study on price transmission in the sugar sector (European Commission, 2012). Additional data was taken from annual reports published by companies operating in the EU market. This article monitors the quota holder situation from the perspective of the EU-28, but the real production quotas for sugar are only in the following countries: Belgium, Bulgaria, The Czech Republic, Denmark, Croatia, France, Finland, Italy, Lithuania, Hungary, Germany, The Netherlands, Poland, Portugal, Romania, Slovakia, Spain, Sweden and The United Kingdom.

Sugar factories are classified into three categories for analysis purposes: sugar factories processing sugar beet, sugar refineries processing cane sugar and combined beet sugar factories/refineries. Alliances controlling EU-sugar quota production are defined not only by their own production units, but also by their joint venture agreements that they have in relation to other partners.

Quota holder system concentration analysis according to HHI and CRn is applied only on sugar quota (quota R 1308/2013) which is supplying the EU-Single Market with sugar for human consumption. HHI is used to measure quota holder system concentration and to monitor anti-monopoly policies. The index ranges from 0 (no concentration and highly competitive system) to 10,000 (pure monopoly) (Hirschman, 1964). The index is calculated by squaring the quota share of each firm competing in a quota system and summing the resulting numbers:

$\mathrm{HHI}=\sum \mathrm{N}_{\mathrm{i}=1} \mathrm{Si}_{\mathrm{i}}^{2}=\mathrm{s}_{1}^{2}+\mathrm{s}_{2}^{2}+\ldots+\mathrm{sN}^{2}$

where $s_{i}$ is the quota share of the firm/alliance "i" in the quota system and $N$ represents the number 
of firms / alliances in the market. HHI is also used by offices for the protection of competition; it is used to measure the impact of mergers and acquisitions. Proofing the quota holder system concentration is according to HHI stricter in Europe where the moderate concentration starts at 1,000, whereas 1,500 is considered in the USA. Classification of market (quota system) concentration in Europe and in the USA is presented in the Table 1.

This article uses HHI classification defined by the US Department of Justice. If the HHI is lower than 0.01 (respectively 100), the market (quota system) is highly competitive. HHI ranging from 0.01 and 0.15 (respectively 100 and 1 500) indicates an un-concentrated market (quota system) with significant positions of several companies. The values of the HHI from 0.15 to 0.25 (respectively 1500 and 2 500) reveals significant market (quota system) concentration (mostly monopolistic competition) and HHI above 0.25 (respectively 2 500 ) indicates highly concentrated market (mostly oligopoly). HHI close to 1 , respectively 10000 suggests a monopoly. The methodology is used to identify the real power and position of countries and firms operating in the European quota sugar system.

The "Four-firm (Five-firm) concentration ratio" was applied as an additional indicator to the HHI. The indicator is computed as follows:

$\mathrm{CR}_{\mathrm{n}}=\sum \mathrm{n}_{\mathrm{i}=1} \mathrm{~S}_{\mathrm{i}}==\mathrm{s}_{1}+\mathrm{s}_{2}+\ldots+\mathrm{s}_{\mathrm{n}}$

where $S_{i}$ is a quota share of a firm $i, n$ represents the number of surveyed subjects within a given sector. The share of firms/alliances was expressed as their partial share in the quota beet sugar production.

Classification of the $\mathrm{CR}_{\mathrm{n}}$ index given by the $\mathrm{DG}$ Comp (2007) results in three categories:

a) Low concentration $(0-50 \%)$ - from perfect competitiveness to oligopoly

b) Moderate concentration $(50-80 \%)$ - pure oligopoly

c) High concentration $(80-100 \%)$ from oligopoly to monopoly

\section{Results and discusion}

The EU sugar market is extremely specific. EU sugar market is operated under the production quota system and it is isolated from the global market through the Common trade and Common agricultural policy. The character of the EU sugar market is also determined by the existence of EU single market and also through the massive subsidy system (Spettmann, 2008;). The European Union is producing about 17 million tonnes of beet sugar and its export capacities have reached about 1.2 million tonnes (European Commission, 2015).

The current EU sugar market is operated by more than one hundred sugar plants - the majority of them are specialized in beet sugar production. Sugar factories are located in $19 \mathrm{EU}$ countries. Their location in EU countries is as follows (the character of individual sugar refineries: sugar beet factories + combined factories + raw sugar/cane factories, source: F. O. Licht Sugar and CEFS): Austria $(2+0+0)$, Belgium $(4+0+0)$, Bulgaria $(0+0+6)$, Croatia $(3+0+0)$, Czech Republic $(7+0+0)$, Denmark $(1+1+0)$, Finland $(1+0+1)$, France $(25+0+1)$, Germany $(20+0+0)$, Greece $(1+0+0)$, Hungary $(1+0+0)$, Italy $(2+2+1)$, Lithuania $(2+0+0)$, the Netherlands $(2+0+0)$, Poland $(16+2+0)$, Portugal $(0+1+3)$, Romania $(0+4+3)$, Slovakia $(2+0+0)$, Spain $(3+2+0)$, Sweden $(1+0+1)$, United Kingdom $(3+1+1)$.

The current state of selected sugar companies in the European sugar market is presented in Table 2. The table shows that approximately fifty companies of various sizes, structures and business strategies currently operate in the EU-market and quota system.

Some of these companies are represented by individual private sugar factories, the others are represented by alliances operating within national markets and quota systems. It is also necessary to highlight the fact that not all companies operating with the EU sugar market are specialized only on sugar production - for some of them sugar production represents only a part of their activities e.g. Südzucker and Tereos.

\begin{tabular}{|l|c|c|c|c|}
\hline & High competitive & Unconcentrated & Moderate concentration & High concentration \\
\hline European Commission & $\mathrm{x}$ & $\mathrm{x}$ & $>1000$ & $>2000$ \\
\hline US Departmet of Justice & $<100$ & $<1500$ & $>1500$ & $>2500$ \\
\hline
\end{tabular}

Source: European Commission, 2010, U.S. Department of Justice and Federal Trade Commission, 2010

Table 1: Market Classification According to HHI Methodology. 


\begin{tabular}{|c|c|}
\hline ABSugar (8 factories in Spain and the UK) & Povazsky cukor, a.s. (1 factory in Slovakia) \\
\hline Acor Sociedad Cooperativa (1 factory in Spain) & Raffinerie Tirlemontoise S.A. (3 factories in Belgium) \\
\hline Agrana Romania S.A. (2 factories in Romania) & RAR Refinarias de Acucar Reunidas, S.A. (1 factory in Portugal) \\
\hline Agrana Zucker GmbH (2 factories in Austria) & Saint Louis Sucre S.N.C. (4 factories in France) \\
\hline Burgarski Zaharni zavodi Ltd. (1 factory in Bulgaria) & SC Zaharul Liesti S.A. (1 factory in Romania) \\
\hline Burgas Zaharen Zavod (1 factory in Bulgaria) & Sermide S.p.A. (1 factory in Italy) \\
\hline COPROB (2 factories in Italy) & Sfir Raffineria di Brindisi (1 factory in Italy) \\
\hline Cristal Union/ CristalCo (10 factories in France) & Slovenské Cukrovary s.r.o. (1 factory in Slovakia) \\
\hline Cukrovar Vrbátky, a.s. (1 factory in the Czech Republic) & $\begin{array}{l}\text { Sociedade de Desenvolvimento Agro-Industrial, S.A. DAI (1 factory } \\
\text { in Portugal) }\end{array}$ \\
\hline Eridania Sadam S.p.A.(1 factory in Italy) & Sociedade de Industrias Agricolas Acorianas, S.A. (1 factory in Portugal) \\
\hline Fabrica De Zahar Bod SA (1 factory in Romania) & Sucros Oy (1 factories in Finland) \\
\hline Hanácká potravinářská společnost. s.r.o. (1 factory in the Czech Republic) & Südzucker AG ( 9 factories in Germany) \\
\hline Hellenic Sugar Industry S.A. (1 factory in Greece) & Südzucker Polska S.A. (5 factories in Poland) \\
\hline ISCAL Sugar (1 factory in Belgium) & Suiker Unie/ Royal Cosun (3 factories in Germany and the Netherlands) \\
\hline Krajowa Spolka Cukrowa S.A. (7 factories in Poland) & $\begin{array}{l}\text { Suomen Sokeri Oy / Finnsugar Ltd. (Nordic Sugar, Nordzucker) } \\
\text { (1 factory in Finland) }\end{array}$ \\
\hline Lesaffre Frčres S.A.S. (1 factory in France) & Tate \& Lyle Sugars ( 1 factory in the UK) \\
\hline Litex Commerce JSC (3 factories in Bugaria) & Tate \& Lyle Açúcares Portugal S.A. (1 factory in Portugal) \\
\hline Litovelská cukrovarna, a.s. (1 factory in the Czech Republic) & Tereos (9 factories in France) \\
\hline Magyar Cukor ZRT. (1 factory in Hungary) & Tereos Ludus (1 factory in Romania) \\
\hline Marr Sugar Romania SRL (1 factory in Romania) & Tereos TTD, a.s. (2 factories in the Czech Republic) \\
\hline Mimo Trading S.R.L. (1 factory in Romania) & Tvornica Secera Osijek d.o.o. (1 factory in Croatia) \\
\hline Moravskoslezské cukrovary, a.s. (2 factories in the Czech Republic) & UAB (1 factory in Lithuania) \\
\hline Nordic Sugar (5 factories in Denmark, Lithuania and Sweden) & VIRO Tvornica secera d.d. (1 factory in Bulgaria) \\
\hline Nordzucker AG (5 factories in Germany) & Zaharen Kombinat Plovdiv AD (1 factory in Bulgaria) \\
\hline Nordzucker Polska S.A. (2 factories in Poland) & Zaharni Zavodi (1 factory in Bulgaria) \\
\hline Ouvré Fils S.A. (1 factory in France) & Zuccherificio del Molise S.p.A. (1 factory in Italy) \\
\hline Pfeifer \& Langen (10 factories in Germany, Poland and Romania) & \\
\hline
\end{tabular}

Source: Source: Licht (2014), CEFS, 2014

Table 2: Selected Sugar Companies in the EU-Market and Quota System, 2013/2014.

The Group Südzucker reached total sales of $€ 7,735$ million in $2013 / 14$. Of that figure, the sugar sector participated by $€ 3,961$ million, which was $50.8 \%$ of total sales. Other market segments were represented by fruit, with a share of $15.15 \%$ and energy crops (biofuels) with $9.3 \%$ in $\mathrm{t}$ total sales.

The Group Tereos (Tereos International) reached total sales of $€ 4,697$ million in $2013 / 14$. Of this sum, sugar beet products (for food and technical use) accounted for $€ 2,011$ million, which was $42.81 \%$ of total sales (France $€ 1,721$ million and the Czech Republic and Romania $€ 290$ million). The cereal and starch sectors represented sales of $€ 1,638$ million $(34.87 \%$ in sales) and cane processing in Brazil, Africa and Indian Ocean area reached $€ 1,031$ million, which represents $21.95 \%$ of the company's total annual sales.

However the number of sugar plants located in individual EU countries is still high, their independency is limited. Many companies are operating within the powerful sugar production alliances or their controlled by those alliances through the capital market. The European sugar production quota system and also beet sugar market is controlled by only six powerful players (Table 3): „Nordzucker “, „Südzucker Alliance“, „Tereos Group Alliance“, „Pfeifer \& Langen Alliance“, „Associated British Food Alliance“" and „Tate \& Lyle Sugars Alliance“. These alliances represent the main pillars of the European sugar market and control not only their own (parent) production capacities, but also the capacities of subsidiaries, or such companies that have entered into these alliances based on purchase or the exchange of shares, or based on agreements of mutual cooperation. The Nordzucker Alliance, for example, controls (coordinates) the production of the following companies: Nordzucker Germany, Nordzucker Polska, Nordic Sugar (Denmark, 


\begin{tabular}{|c|c|c|c|}
\hline & Alliance/Company & Headquarters & $\begin{array}{l}\text { Share of sugar output } \\
\text { in the EU-market (\%) }\end{array}$ \\
\hline 1 & Südzucker-Gruppe & Germany & 24.1 \\
\hline 2 & Nordzucker AG & Germany & 15 \\
\hline 3 & Tereos & France & 10.9 \\
\hline 4 & Associated British Foods (British Sugar) & United Kingdom & 10.8 \\
\hline 5 & Pfeifer \& Langen & Germany & 8.0 \\
\hline TOP 5 & & & 68.8 \\
\hline 6 & Suiker Unie/ Royal Cosun & The Netherlands & 7 \\
\hline 7 & Cristal Union/ CristalCo & France & 6.9 \\
\hline 8 & Tate \& Lyle Sugars (has no quota) & United Kingdom & 5 \\
\hline 9 & Polski Cukier & Poland & 3 \\
\hline 10 & SFIR (has no quota, only refining) & Italy & 2 \\
\hline TOP 10 & & & 92.7 \\
\hline
\end{tabular}

Source: CEFS, Licht (2014), own calculation, 2014

Table 3: Producers Controlling the EU-Sugar Market (Sugar Output from Cane and Beet).

Lithuania, Finland and Sweden), Povážský cukor (Slovakia). With the exception of the above mentioned capacities owned and managed directly by Nordzucker, Nordzucker has also bought a onethird share in the Cukrovary TTD - however that sugar factory located in the Czech Republic is controlled by Tereos Group.

The „Südzucker Alliance“ controls/coordinates: Südzucker AG Germany, Südzucker Polska S.A., Raffinerie Tirlemontoise S.A. (Belgium), Saint Louis Sucre S.N.C. (France), Agrana Zucker GmbH (Austria), Magyar Cukor ZRT (Hungary), Slovenské cukrovary s.r.o. (Slovakia), Moravskoslezské cukrovary a.s. (Czech Republic), Agrana Romania S.A. (Romania). Südzucker AG, through Saint Louis Sucre, owns 44\% of the shares of Ouvré Fils S.A. (Souppes) in France.

„Tereos Group Alliance“controls: Tereos (France), Cukrovary TTD (Czech Republic - about 62\%) and has an agreement for the refining of raw sugar with Acor (Spain).

„Pfeifer \& Langen Alliance“ controls: Pfeifer \& Langen Germany, Pfeifer \& Langen Polska, Pfeifer \& Langen Romania and $50 \%$ of Italia Zuccheri (Italy), which markets the beet sugar produced by CoProB and the sugar refined at Minerbio.

„Associated British Food“ is active mostly in the United Kingdom and Spain. Currently, the alliance controls: British Sugar (UK) and Azucarera (Spain; ABF/BSG owner of 100\%), Billington's (UK; ABF/BSG owner of $100 \%$ ), Czarnikow Group (UK; ABF owner of $42.5 \%$ ), Mitra Sugar Ltd (UK) and Silver Spoon (UK).
The above mentioned facts show that the alliances control a much higher market share than apparent when market shares according their parent companies are judged. Sugar companies are interconnected not only by their assets but also by a number of marketing agreements etc.

The ownership structure of sugar companies or alliances is also quite complex, which is presented in the Table 4.

Analysing ownership structures in detail shows additional complications. Because sugar quotas willbeabolished in thenearfuture, the European sugar market will become more interesting for investors outside of the EU. For example, the Group ASR (American Sugar Refining, Inc.), headquartered in the USA has already taken over ED\&F Man's $50 \%$ share in SFIR Raffineria di Brindisi in Italy. ASR Group is also the owner of Tate\&Lyle Sugars, which controls 2 refineries in the United Kingdom and Portugal.

The concentration of EU sugar quota production capacities

Sugar production quotas is not distributed equally among individual EU countries: Austria 2.59\%, Belgium 5\%, Croatia 1.43\%, Czech Republic 2.75\%, Denmark 2.75, Finland $0.6 \%$, France $22.21 \%$, Germany $21.42 \%$, Greece $1.17 \%$, Hungary $0.78 \%$, Italy $3.76 \%$, Lithuania $0.67 \%$, Netherlands $5.95 \%$, Poland $10.39 \%$, Romania $0.77 \%$, Slovakia $0.83 \%$, Spain 3.68\%, Sweden $2.17 \%$ and United Kingdom $7.81 \%$ ). However the production quotas are in theory distributed among individual countries, their owners are not individual governments. Their real owners are individual sugar producing 


\begin{tabular}{|c|c|}
\hline $\begin{array}{l}\text { Südzucker AG } \\
\text { Mannheim, Germany }\end{array}$ & $\begin{array}{l}52 \% \text { shares owned by the cooperative SGVZ* (Alliance of East-German sugar beet producers) } \\
10 \% \text { shares owned by Zucker Invest GmbH (owner of Agrana) } \\
38 \% \text { freely traded shares on the Frankfurt Stock Exchange }\end{array}$ \\
\hline Braunschweig, Germany & $\begin{array}{l}84.1 \% \text { NGA** Nordzucker Holding AG (joint-stock company) } \\
10.8 \% \text { Union-Sugar North-Hannover Company (UZS)*** } \\
5.1 \% \text { other owners - direct interests } \\
\text { Shares are not freely traded - the owners are mostly beet suppliers to Nordzucker AG. }\end{array}$ \\
\hline $\begin{array}{l}\text { Associated British Foods } \\
\text { London, United Kingdom }\end{array}$ & $\begin{array}{l}54.5 \% \text { shares owned by Wittington Investments ( } 79.2 \% \text { share in Wittington Investments is owned } \\
\text { by Garfield Weston Foundation****) } \\
45.5 \% \text { shares owned by other shareholders (mostly funds, small investors) } \\
\text { Shares listed at London Stock Exchange. }\end{array}$ \\
\hline $\begin{array}{l}\text { Tereos } \\
\text { Tereos Union de Cooperatives Agricoles } \\
\text { Origny Sainte-Benoite }\end{array}$ & $\begin{array}{l}\text { Tereos is a co-operative owned by 12,000 French sugar beet producers (cooperative union). } \\
\text { Tereos' shareholding structure - cooperatives: Union SDA (SDA, CBA, SHP), Union BS (Boiry, } \\
\text { Chevrières, Connantre, Escaudoeuvres), SDHF - Sucreries et Distilleries des Hauts de France, } \\
\text { CFH and CFVA. }\end{array}$ \\
\hline $\begin{array}{l}\text { Pfeifer \& Langen GmbH \& Co. KG } \\
\text { Köln, Germany }\end{array}$ & $\begin{array}{l}\text { Quite specific ownership structure (family owned company) in form of a limited partnership. } \\
\text { Headquartes is in Cologne, Germany, the company is registered in Belgium. }\end{array}$ \\
\hline $\begin{array}{l}\text { Royal Cosun (Suiker Unie) } \\
\text { Breda, Netherlands }\end{array}$ & Royal Cosun- cooperative of Dutch sugar beet growers (about 11000 members) \\
\hline $\begin{array}{l}\text { Cristal Union } \\
\text { Paris, France }\end{array}$ & Cooperative representing about $40 \%$ of sugar beet growers in France. \\
\hline $\begin{array}{l}\text { Polski Cukier } \\
\text { - Krajowa Spółka Cukrowa } \\
\text { Spółka Akcyjna } \\
\text { Toruń, Poland }\end{array}$ & $\begin{array}{l}79.52 \% \text { shares in state ownership of Poland } \\
20.48 \% \text { shares owned by employees and sugar beet growers }\end{array}$ \\
\hline
\end{tabular}

Notes: *SGVZ = Süddeutsche Zuckerrübenverwertungs-Genossenschaft eG, **NGA Nordzucker Holding Aktiengesellschaft, *** Union-Zucker Südhannover Gesellschaft mit beschränkter Haftung, **** Garfield Weston Foundation is one of the UK largest grant-making charitable trusts, and the remainder is owned by members of the Weston family.

Source: CEFS, Licht (2014), European Commission, annual reports of sugar companies, 2014

Table 4: Ownership Structure of the most Important Sugar Companies/Alliances in the EU.

companies operating with the EU sugar market. Table 5 gives an overview of the percentage proportion of major European companies on beet sugar quotas (quota R 1308/2013). It is evident that the beet sugar production is in hands of a few subjects (alliances) which de-facto control individual national sugar quotas. On the base of the findings coming from the table below it is evident that the EU quota system is controlled by only five the following operators: Südzucker, Nordzucker, Associated British Foods, Tereos and Pfeifer \& Langen. German and French companies are playing the leading role within the quota system.

Table 6 gives an overview of national quota (R 1308/2013) distribution at the level of companies (alliances) headquartered in Germany and France. The following percentage of quota R 1308/2013 beet sugar production quota is controlled by only five alliances in the EU: France (98\%), Germany (96\%), Poland (61\%), Belgium (72\%), Italy (79\%), Spain (26\%), Czech Republic (81\%), Denmark $(100 \%)$, Austria $(100 \%)$, Sweden $(100 \%)$, Croatia $37 \%$, Slovakia (100\%), Romania (94\%), Hungary $(100 \%)$, Finland $(100 \%)$ and Lithuania $(71 \%)$. The EU-quota holder system is dominated mostly by German and French alliances Südzucker-Gruppe, Nordzucker AG, Pfeifer \& Langen, Tereos Group a Cristal Union, which control together more than $72 \%$ quota R 1308/2013 beet sugar production. The "Five-firm concentration ratio" (additional indicator to the HHI) was calculated and value of the indicator achieved $72.1 \%$ (i.e moderate concentration - pure oligopoly).

Table 6 gives an overview of national quota (R 1308/2013) distribution at the level of companies 


\begin{tabular}{|c|c|c|c|c|c|c|c|c|c|}
\hline EU-country* & Südzucker & Nordzucker & $\begin{array}{l}\text { Associated } \\
\text { British Foods }\end{array}$ & Tereos & $\begin{array}{l}\text { Pfeifer } \\
\text { \& Langen }\end{array}$ & $\begin{array}{l}\text { Suiker Unie/ } \\
\text { Royal Cosun }\end{array}$ & $\begin{array}{l}\text { Cristal Union/ } \\
\text { CristalCo }\end{array}$ & $\begin{array}{l}\text { KSC } \\
\text { Polski Cukier } \\
\text { S.A. }\end{array}$ & Others \\
\hline France (without DOM) & $20 \%$ & & & $41 \%$ & & & $37 \%$ & & $2 \%$ \\
\hline Germany & $40 \%$ & $34 \%$ & & & $22 \%$ & $4 \%$ & & & \\
\hline Poland & $25 \%$ & $9 \%$ & & & $26 \%$ & & & $39 \%$ & \\
\hline United Kingdom & & & $100 \%$ & & & & & & \\
\hline Belgium & $72 \%$ & & & & & & & & $28 \%$ \\
\hline Italy & & & & & $56 \%$ & & $23 \%$ & & $21 \%$ \\
\hline Spain & & & $74 \%$ & $26 \%$ & & & & & \\
\hline Czech Republic** & $25 \%$ & & & $56 \%$ & & & & & $19 \%$ \\
\hline Croatia & & & & & $37 \%$ & & & & $63 \%$ \\
\hline Greece & & & & & & & & & $100 \%$ \\
\hline Slovakia & $39 \%$ & $61 \%$ & & & & & & & \\
\hline Romania & $35 \%$ & & & $32 \%$ & $27 \%$ & & & & $6 \%$ \\
\hline Hungary & $100 \%$ & & & & & & & & \\
\hline Lithuania & & $71 \%$ & & & & & & & $29 \%$ \\
\hline Finland & & $100 \%$ & & & & & & & \\
\hline
\end{tabular}

Notes: * Azores and French DOM are not included

**The quota is divided among Suedzucker (Agrana)=Moravskoslezské cukrovary a.s., Tereos (+Nordzucker)=Tereos TTD a.s.

(Dobrovice) and three other smaller companies in the Czech Republic

Source: CEFS, Licht (2014), EU, DG AGRI, own calculation 2014

Table 5: Shares of Sugar Companies in Quota R 1308/2013 Sugar Production in EU-Member States.

\begin{tabular}{|c|c|c|c|c|}
\hline EU-country* & $\begin{array}{c}\text { Sum Südzucker + Nordzucker } \\
+ \text { Pfeifer \& Langen }\end{array}$ & $\begin{array}{c}\text { Sum (tonnes) } \\
\text { Südzucker + Nordzucker } \\
\text { + Pfeifer \& Langen }\end{array}$ & $\begin{array}{l}\text { Sum Tereos + Cristal } \\
\text { Union/ CristalCo }\end{array}$ & $\begin{array}{c}\text { Sum (tonnes) } \\
\text { Tereos + Cristal Union/ } \\
\text { CristalCo }\end{array}$ \\
\hline France (without DOM) & $20 \%$ & 600962 & $78 \%$ & 2343753 \\
\hline Germany & $96 \%$ & 2782326 & $0 \%$ & 0 \\
\hline Poland & $61 \%$ & 855508 & $0 \%$ & 0 \\
\hline United Kingdom & $0 \%$ & 0 & $0 \%$ & 0 \\
\hline The Netherlands & $0 \%$ & 0 & $0 \%$ & 0 \\
\hline Belgium & $72 \%$ & 486889 & $0 \%$ & 0 \\
\hline Italy & $56 \%$ & 284692 & $23 \%$ & 116927 \\
\hline Spain & $0 \%$ & 0 & $26 \%$ & 129605 \\
\hline Czech Republic & $25 \%$ & 93973 & $40 \%$ & 208716 \\
\hline Denmark & $100 \%$ & 372383 & $0 \%$ & 0 \\
\hline Austria & $100 \%$ & 351027 & $0 \%$ & 0 \\
\hline Sweden & $100 \%$ & 293186 & $0 \%$ & 0 \\
\hline Croatia & $37 \%$ & 71364 & $0 \%$ & 0 \\
\hline Greece & $0 \%$ & 0 & $0 \%$ & 0 \\
\hline Slovakia & $100 \%$ & 112320 & $0 \%$ & 0 \\
\hline Romania & $62 \%$ & 65189 & $32 \%$ & 33396 \\
\hline Hungary & $100 \%$ & 105420 & $0 \%$ & 0 \\
\hline Lithuania & $71 \%$ & 64200 & $0 \%$ & 0 \\
\hline Finland & $100 \%$ & 80999 & $0 \%$ & 0 \\
\hline Total (EU Quota) & $50.59 \%$ & 6620905 & $21.6 \%$ & 2832397 \\
\hline
\end{tabular}

Notes: ** Azores and French DOM are not included

Source: CEFS, Licht (2014), EU, DG AGRI, own calculation 2014

Table 6: Share of biggest German and French Sugar Producers in Quota R 1308/2013: Sugar Beet Quota Production in the EU. 
(alliances) headquartered in Germany and France. The following percentage of quota R 1308/2013 beet sugar production quota is controlled by only five alliances in the EU: France (98\%), Germany (96\%), Poland (61\%), Belgium (72\%), Italy (79\%), Spain (26\%), Czech Republic (81\%), Denmark $(100 \%)$, Austria (100\%), Sweden (100\%), Croatia $37 \%$, Slovakia (100\%), Romania (94\%), Hungary $(100 \%)$, Finland (100\%) and Lithuania (71\%). The EU-quota holder system is dominated mostly by German and French alliances Südzucker -Gruppe, Nordzucker AG, Pfeifer \& Langen, Tereos Group a Cristal Union, which control together more than $72 \%$ quota R $1308 / 2013$ beet sugar production. The "Five-firm concentration ratio" (additional indicator to the HHI) was calculated and value of the indicator achieved $72.1 \%$ (i.e moderate concentration - pure oligopoly).

If we apply the HHI Index we can see that the sugar market operating under the production quota system is concentrated in almost all surveyed Member States (France 3454; Germany 3256; Poland 2938; United kingdom 10000; Netherlands 10000; Belgium 5968; Italy 4106; Spain 6152, Czech republic 2842; Denmark 10000; Austria 10000; Sweden 10000; Croatia 5741; Greece 10000; Slovakia 5242; Romania 3338; Hungary 10000; Lithuania 10000; Finland 10000).
When performing an evaluation of the European quota beet sugar holder system, a paradox appears. While the quota holder system of individual EU-Member States is highly concentrated, the EU-quota holder system as a whole seems to have a relatively low concentration.

When performing the analysis over the last twenty or thirty years, it is evident, that the sugar quota holder system in the EU is becoming more and more concentrated. In regards to the future, it is difficult to predict further development of the EU-market due to expected sugar quota abolition. Nevertheless, it can be stated that the quota abolition, without opening the EU-market to sugar imports from third countries will be exploited by large companies. The quota elimination could lead to the displacement of small and independent producers and would probably strengthen the position of the already big players. One can only guess whether these players will compete with each other or if they will divide the spheres of influence among themselves like the cartel of three German largest alliances have in the past. The EU-antitrust authorities will play an important role in such a case. The next EU-sugar market development may be also influenced by the WTO negotiations, however these are very complicated.

\begin{tabular}{|c|c|c|c|c|c|c|c|}
\hline $\begin{array}{l}\text { EU country (capacities } \\
\text { allocated to concrete } \\
\text { states) }\end{array}$ & $\begin{array}{l}\text { Sugar production } \\
\text { quota } 2013 / 2014\end{array}$ & $\begin{array}{l}\text { Share in } \\
\text { production }\end{array}$ & HHI by quota & $\begin{array}{l}\text { EU country (capacities } \\
\text { controlled by concrete } \\
\text { countries through } \\
\text { headquartered companies) }\end{array}$ & $\begin{array}{l}\text { Sugar production } \\
\text { quota } 2013 / 2014\end{array}$ & $\begin{array}{l}\text { Share in } \\
\text { production }\end{array}$ & $\begin{array}{c}\text { HHI by } \\
\text { headquarters }\end{array}$ \\
\hline France (without DOM) & 3004811 & $23.30 \%$ & \multirow{19}{*}{1364.8} & France (without DOM) & 2799364 & $21.71 \%$ & \multirow{19}{*}{3225} \\
\hline Germany & 2898256 & $22.48 \%$ & & Germany & 6486110 & $50.30 \%$ & \\
\hline Poland & 1405608 & $10.90 \%$ & & Poland & 548187 & $4.25 \%$ & \\
\hline United Kingdom & 1056474 & $8.19 \%$ & & United Kingdom & 1579966 & $12.25 \%$ & \\
\hline The Netherlands & 804888 & $6.24 \%$ & & The Netherlands & 920818 & $7.14 \%$ & \\
\hline Belgium & 676235 & $5.24 \%$ & & Belgium & 189346 & $1.47 \%$ & \\
\hline Italy & 508379 & $3.94 \%$ & & Italy & 106760 & $0.83 \%$ & \\
\hline Spain & 498480 & $3.87 \%$ & & Spain & 0 & $0.00 \%$ & \\
\hline Czech Republic & 372459 & $2.89 \%$ & & Czech Republic & 70767 & $0.55 \%$ & \\
\hline Denmark & 372383 & $2.89 \%$ & & Denmark & 0 & $0.00 \%$ & \\
\hline Austria & 351027 & $2.72 \%$ & & Austria & 0 & $0.00 \%$ & \\
\hline Sweden & 293186 & $2.27 \%$ & & Sweden & 0 & $0.00 \%$ & \\
\hline Greece & 158702 & $1.23 \%$ & & Greece & 158702 & $1.23 \%$ & \\
\hline Slovakia & 112320 & $0.87 \%$ & & Slovakia & 0 & $0.00 \%$ & \\
\hline Romania & 104689 & $0.81 \%$ & & Romania & 34547 & $0.27 \%$ & \\
\hline Hungary & 105420 & $0.82 \%$ & & Hungary & 0 & $0.00 \%$ & \\
\hline Lithuania & 90252 & $0.70 \%$ & & Lithuania & 0 & $0.00 \%$ & \\
\hline Finland & 80999 & $0.63 \%$ & & Finland & 0 & $0.00 \%$ & \\
\hline Total & 12894568 & $100.00 \%$ & & Total & 12894568 & $100.00 \%$ & \\
\hline
\end{tabular}

Notes: *Azores, French DOM and Croatia are not included

Source: CEFS, Licht (2014), EU, DG AGRI, own calculation 2014

Table 7: EU Quota Holder Concentration by Country (by Allocated Disposable Quotas of a Country) and by Production Capacities Controlled by Country (by Allocated Quotas of Companies/Alliances Headquartered in a given Country) 


\section{Conclusion}

The European sugar production quota system is extremely concentrated and it is becoming more and more dominated by fewer players. The main actors are especially German, French and Dutch sugar producing companies. Dominant role is kept especially by Südzucker, Nordzucker, Tereos and Pfeifer and Langen. These and also other subjects operating on EU sugar market under the sugar quota system are operating under the very comfortable conditions existing within the EU-market. The EU market is not only regulated one, but it is also heavily protected against imports coming from abroad. Imports (including also raw cane sugar) are hindered by high duties (EUR 339 per ton of raw cane sugar and EUR 419 per ton of white sugar). The only significant exception of the EU-sugar market protection is represented by LDCs respectively ACP countries (From 1 October 2009 to 30 September 2015: ACPs have free access to the market, the only restriction being an automatic safeguard clause for non-LDC ACPs. The new trade arrangements are stated in Commission Regulation (EC) No 828/2009. In 2014, ACP exports of sugar to the EU accounted for cc $1.3 \mathrm{~m}$ tonnes (European Commission, 2015). New subjects have no opportunity to penetrate the market because the beet sugar quota is "sold out". Sugar companies operating in the EU-market are mutually linked by property and contracts. The market is therefore more concentrated than it seems at first glance.

Sugar quota is distributed among 19 EU-Member States. In this regard, the quota is generous, especially in relation to France, Germany, Poland and United Kingdom. A great concentration of disposable quota sugar production capacities is evident at the level of Member States (and companies/alliances operating in Member States) which considerably eliminates a competition there. The quota production is carried out through a very limited number of subjects (alliances) in many Member States, which de-facto control national quota holder systems. An extreme situation can be found in Finland, Lithuania, Hungary, Sweden, Denmark, the Netherlands, Belgium, United Kingdom and Slovakia, where the allocated national quota is controlled by one or two subjects (company, alliance). The capacities (national quotas) in northern countries, i.e.Denmark, Sweden andFinland are fully controlled by the alliance Nordzucker. Contrary, national quotas R 1308/2013 in Austria, Hungary, Slovakia and Belgium are controlled (from $61 \%$ to $100 \%$ ) by the alliance Südzucker.

When assessing the EU as one common quota holder system, the situation seems to be ideal from the perspective of quota and production capacities distribution. In the reality, this state is only apparent, the quota system is concentrated, in hands of a small number of alliances headquartered mostly in three (respectively four) countries. The EU-quota holder system is dominated mostly by German and French alliances Südzucker -Gruppe, Nordzucker AG, Pfeifer \& Langen, Tereos Group a Cristal Union, which control together more than $72 \%$ quota R $1308 / 2013$ beet sugar production (pure oligopoly) and share about $65 \%$ in the total EU-sugar market (including out of quota sugar production).

\section{Acknowledgements}

This paper was supported by the Grant Agency at the Faculty of Economics and Management, Czech University of Life Sciences Prague: The selected aspects of economy sanctions and their impact on mutual trade between EU and Russia [nr. 20151031].

Corresponding author:

Ing. Helena Řezbová, Ph.D.

Department of Economics, Faculty of Economics and Management, Czech University of Life Sciences Prague Kamýcká 129, 16521 Prague 6, Czech Republic

Phone: +42022438 2087,E-mail: rezbova@pef.czu.cz

\section{References}

[1] CEFS, CEFS SUGAR STATISTICS 2014 [Online]. Available: http://www.comitesucre.org/site/ statistics/ [Accessed 20 March 2015]. 
[2] DG Comp, London economics in association with global energy decisions: Structure and Performance of Six European Wholesale Electricity Markets in 2003, 2004 and 2005, presented to DG Comp $26^{\text {th }}$ February 2007, p. 52 and p. 8, [Online] Available: http://ec.europa.eu/competition/sectors/energy/inquiry/electricity_final_part4.pdf [Accessed: 25 Aug 2014].

[3] Licht, F. O. International-sugar-and-sweetener-report, 2014. [Online]. Available: https://www.agranet.net/agra/international-sugar-and-sweetener-report/login/ [Accessed: 22 May 2015].

[4] European Commission, DG Agriculture and Rural Development. TENDER $\mathrm{N}^{\circ}$ AGRI-2011-EVAL-03, Study on price transmission in the sugar sector, Final report, October 2012.

[5] Chapter: 7.2. Effects of the reform on concentration and competition in the sugar sector. $118 \mathrm{~s}$. [Online] Available: http://ec.europa.eu/agriculture/external-studies/2012/sugar-price-transmission/ fulltext_en.pdf [Accessed: 2 July 2015].

[6] European Commission. Sugar and isoglucose balance sheets, 2014, Committee for the Common Organisation of Agricultural Markets. [Online] Available at: http://ec.europa.eu/agriculture/sugar/ balance-sheets/balance-sheet_en.pdf. [Accessed: 27 May 2015].

[7] European Commission. EU Sugar Balance [Online] Available: http://ec.europa.eu/agriculture/ sugar/balance-sheets/presentation_en.pdf. [Accessed: 5 May 2015].

[8] European Commission. Germany: The Bundeskartellamt imposes Fines on Sugar Manufacturers for Cartel Agreements [Online] Available: http://ec.europa.eu/competition/ecn/brief/02_2014/de_ sugar.pdf. [Accessed 12 March 2015].

[9] European commission. Key commodities for ACP countries [Online] Available: http://ec.europa. eu/agriculture/developing-countries/commodities/index_en.htm. [Accessed 7 March 2015].

[10] Gohin, A., Bureau, J. C. Sugar market liberalization: Modelling the EU supply of "C" sugar. In Paper prepared for presentation at the $\mathrm{XI}^{\text {th }}$ European association of agricultural economists conference Copenhagen, Denmark, August 24, 2005.

[11] Gotor, E. The reform of the EU sugar trade preferences toward developing countries in light of the economic partnership agreements, The Estey Centre for Law and Economics in International Trade, The Estey Centre Journal of International Law and Trade Policy. 2009, Vol. 10, No. 2, p.15-29. ISSN 1496-5208.

[12] Hirschman, A. O. The Paternity of an Index, The American Economic Review (American Economic Association), 1964, Vol. 54, No. 5, p. 761. ISSN 0002-8282.

[13] Chochola, J., Pulkrábek. Sugar Beet Research in the World, Listy cukrovarnické a řepařské, 2012, Vol. 128, No. 5-6, p.177-179, ISSN 1210-3306.

[14] Neundoerfer, M., European sugar policy. Unde venit - Quo vadit. 2011. Zuckerindustrie /Sugar Industry 136, (5), p. 317-324, ISSN: 0344-8657

[15] Nolte, S., Grethe, H., Development of the EU and world sugar markets in 2011. Zuckerindustrie /Sugar Industry, 2012, Vol. 137, No. 1, p. 40-48. ISSN 0344-8657.

[16] Nolte, S., Grethe, H., EU and world sugar markets in 2010. Zuckerindustrie /Sugar Industry. 2011, Vol. 136, No. 2, p. 90-100. ISSN 0344-8657.

[17] Nolte, S., Buysse, J., Van der Straeten, B. , Claeys, D., Lauwers, L. Preferential sugar imports of the EU. International sugar journal, 2011, Vol. 113, No. 1346, p. 93-101. ISSN: 0020-8841.

[18] Nolte, S., Buysse, J., Van Huylenbroeck, G. Abolition of the EU sugar quotas - what's at stake? International sugar journal. 2014, Vol. 114, No. 1359, p. 146-150. ISSN 0020-8841.

[19] Machek, O., Špička, J. Measuring Performance Growth of Agricultural Sector: A Total Factor Productivity Approach. International Journal of Economics and Statistics. 2013, Vol. 1, No. 4, p. 200-208. ISSN 2309-0685. 
[20] Severová, L., Bendl, S. Cartels and its behaviour on food markets. Agricultural Economics (Zemědělská ekonomika). 2013, Vol. 59, No. 2, p. 81-89. ISSN 0139-570X.

[21] Smutka, L., Benešová, I., Pulkrábek, J. The World Trade of White Sugar, Listy cukrovarnické a řepařské, 2012, Vol. 128, No. 3, p. 86-89. ISSN 1210-3306.

[22] Smutka, L., Benešová, I., Pulkrábek, J. Analýza konkurenceschopnosti vzájemného obchodu se surovým a bílým cukrem mezi jednotlivými regiony světa (Analysis of competitiveness of mutual trade with raw and white sugar among particular world regions, in Czech). Listy cukrovarnické a řepařské. 2012, Vol. 128, No. 4, p. 141-145. ISSN 1210-3306.

[23] Smutka, L., Rumánková, L., Pulkrábek, J., Benešová, I. Main Determinants of Supply and Demand on World Sugar Market, Listy cukrovarnické a řepařské. 2013, Vol. 129, No. 4, p. 142-145. ISSN 1210-3306.

[24] Smutka, L., Rumánková, L., Pulkrábek, J., Benešová, I. The Relationship between Brazilian and World Sugar Markets. Listy cukrovarnické a řepařské, 2015, Vol. 131, No. 5-6, p. 194 -198. ISSN 1210-3306.

[25] Smrčka, L., Hoenig, V., Hromádko, J. Where is the Future of Sugar Industry in the Czech Republic, Listy cukrovarnické a řepařské, 2012, Vol. 128, No. 5-6, p. 193-198 ISSN 1210-3306.

[26] Strnadová, H., Actual progress and perspective of sugar-beet and sugar market, Listy cukrovarnické a řepařské 2009, Vol. 125, p. 334 -340. ISSN 1210-3306.

[27] Spettmann, T. European sugar in a competitive World. Zuckerindustrie / Sugar Industry, 2008, Vol. 133, No. 9, p. 589-595. ISSN 0344-8657.

[28] Špička, J., Janotová, B. Cost of sugar beet growing in the Czech Republic and international comparison, Listy cukrovarnické a řepařské, 2013, Vol. 129, No. 7-8, p. 210-214. ISSN 1210-3306. 